\title{
Presence of blue whale (Balaenoptera musculus) IN THE NORTHWESTERN COAST OF CHILOÉ IsLAND, SOUTHeRn ChILE
}

\author{
Elsa Cabrera ${ }^{1}$, Carole A. Carlson ${ }^{2}$ and Bárbara Galletti Vernazzani ${ }^{1}$
}

Although some populations of blue whales (Balaenoptera musculus) appear to be increasing after gaining legal protection from commercial whaling in 1966 (NMFS, 1998), others are not (Clapham et al., 1999). In the Southern Hemisphere alone, more than 350,000 blue whales were taken by whaling fleets from 1904 to 1967 and thousands more were killed, but not reported, by Soviet whaling fleets in the 1960s and 1970s (Reeves et al., 2003). In Chile, commercial whaling started at the end of the $18^{\text {th }}$ century and by 1900 Punta Arenas (Region XII), Chiloé and Valdivia (Region X) had become important whaling stations. Historical records of blue whales in Chile describe a former whaling area around Chiloé Island and the Corcovado Gulf (Aguayo-Lobo et al., 1998), approximately between $41^{\circ} 15^{\prime} \mathrm{S}$ and $43^{\circ} 30^{\prime} \mathrm{S}$. In 2003, the western side of Chiloé Island and the Corcovado Gulf were identified as one of the most important blue whale feeding and nursing grounds discovered to date in the Southern Hemisphere (Hucke-Gaete et al., 2004). Here we present recent records of blue whales made in the northwestern region of Chiloé Island, between $41^{\circ} 45^{\prime} \mathrm{S}$ and $42^{\circ} 15^{\prime} \mathrm{S}$, that complement those observations reported by Hucke-Gaete et al. (2004) and are among the first in this area since the end of commercial whaling operations in Chilean waters. The research work was developed under the Southern Right Whale Project/Chile that the Cetacean Conservation Center (CCC) has been carrying out since February 2003 in order to investigate the presence of great whales in the northern Chiloé Island.
Between 16 February and 17 March 2004, weather permitting, CCC developed land-based observations, two marine surveys on board fishermen vessels and one aerial survey on board a Chilean Marine Navy aircraft. Trained observers working from land-based platforms located at a height of $38 \mathrm{~m}$ and $58 \mathrm{~m}$ above sea level, and using $12 \times 50$ binoculars, conducted 29 days of observations lasting on average $6.6 \mathrm{~h}(\mathrm{SD}=3.3 \mathrm{~h})$ during daylight hours of 08:00 - 20:30. With 190.9 h of land-based effort, balaenopterids were observed and identified during all days. The maximum number of balaenopterids sighted daily varied from 2 to 19 individuals, with an average of $9.03(\mathrm{SD}=4.7)$ whales per day. On six occasions and from different observation platforms, the whales were positively identified as B. musculus (Figure 1, Table 1).

When whales were sighted from land-based platforms, observers estimated the distance of the whales to the coast (Table 1) and the reported location refers to the geographic coordinates of the platform. When whales were sighted from marine or aerial platforms, the distance of the whale(s) to the coast was calculated using GPS coordinates and in these cases, the location refers to the actual position of the whale. The near proximity of deep water to cliff-based sighting stations allowed the documentation of feeding behavior and defecation from land as well as during marine surveys.

The presence of blue whales and the observations of defecation in the northwestern area of Chiloé Island suggest that the feeding and nursing ground identified

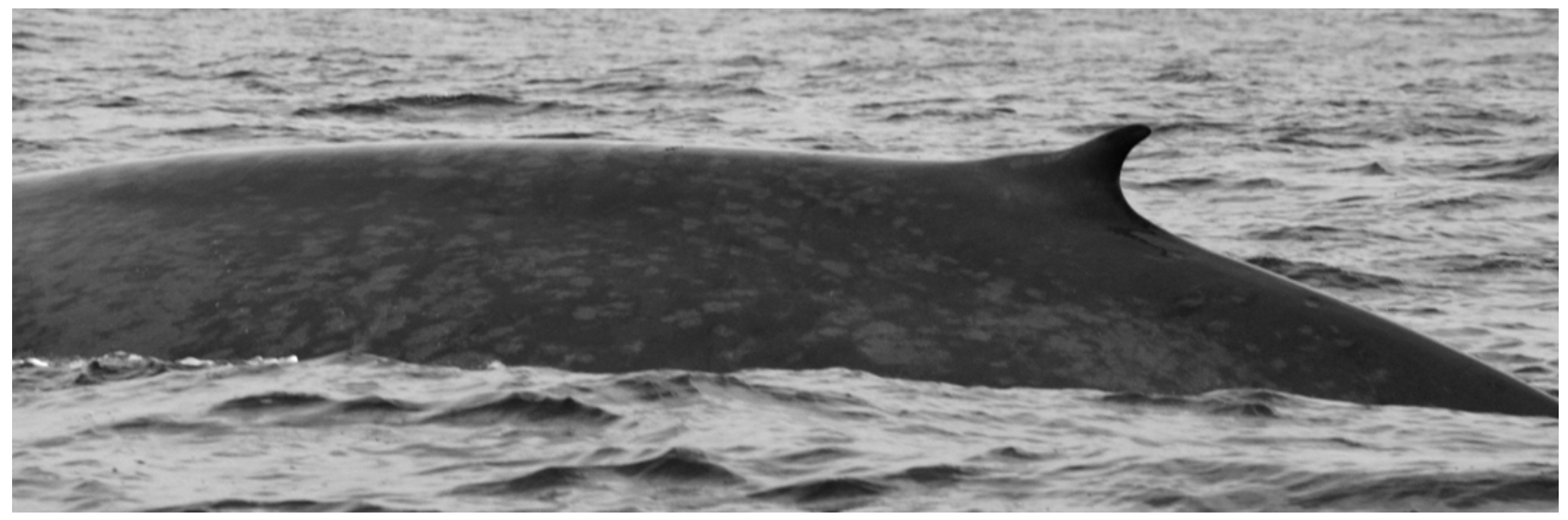

Figure 1. Blue whale photographed off northwestern Chiloé Island, Chile (photo: CCC12/03/04).

\footnotetext{
${ }^{1}$ Cetacean Conservation Center (CCC). Casilla 19178 Correo 19, Santiago, Chile.

${ }^{2}$ International Fund for Animal Welfare (IFAW) - 411 Main Street, Yarmouth Port, MA 02675-1822, USA.
} 
by Hucke-Gaete et al. (2004) could at least extend as far north as $41^{\circ} 45^{\prime} \mathrm{S}$. Taking into account the endangered status of the Southeast Pacific blue whale population ${ }^{3}$ and considering that the main factors limiting marine mammal abundance are the availability of secure breeding and feeding grounds (Harwood et al., 1996), the implementation of a marine protected area (MPA) in this blue whale nursing and feeding ground of the Chiloé and Corcovado region, including the northwestern area of Chiloé Island, should be a high priority issue for government authorities, as pointed out by Hucke-Gaete et al. (2004).

\section{Acknowledgements}

We wish to thank the Direction of Maritime Territory (DIRECTEMAR) from the Chilean Navy and International Fund for Animal Welfare (IFAW) for the essential financial and logistic support for the development of the Southern Right Whale Project/Chile Summer 2004 Field Work. We also wish to thank Miguel and Francisco Altamirano, the Punihuil fishermen community and Luis Clausen for their cooperation during our field work. Particularly, we wish to thank the CCC team: Andrea Bahamonde, Ana Guzman, Karina Diaz, Philippe Guichard and Verónica Altayo for developing field work and collecting information. Finally we wish to acknowledge Rodrigo Hucke-Gaete and two other anonymous referees for the improvements made to the article.

\section{References}

Aguayo-Lobo, A., Torres, D. And Acevedo, J. (1998) Los mamíferos marinos de Chile: I. Cetacea. Serie Científica INACH (Chile) 48: 19-159.

Clapham, P.J., Young, S.B. and Brownell Jr., R.L. (1999) Baleen whales: conservation issues and the status of the most endangered populations. Mammal Review 29: 35-60.

Harwood, J. And Rohani, P. (1996) The population biology of marine mammals. Pages 173-190 in FLoYd, R.B., SHePrARD, A.W. AND De BARRO, P.J. (Eds) Frontiers in Population Ecology. CSIRO Publishing, Melbourne.

Hucke-Gaete, R., Osman, L.P., Moreno, C., Findlay, K.P. AND LjungBLAD, D.K. (2004) Discovery of a blue whale feeding and nursing ground in southern Chile. Proceedings of the Royal Society of London B (Supplement.), Biology Letters 271: S170-S173.

National Marine Fisheries Service (NMFS) (1998) Recovery plan for the blue whale (Balaenoptera musculus). Prepared by Reeves R.R., Clapham, P.J., Brownell, R.L., Jr., and Silber, G.K. for the National Marine Fisheries Service, Silver Spring, MD. 42 pp.

Reeves, R.R., Smith, B.D., Crespo, E.A. And Di Sciara, G.N. (Compilers) (2003) Dolphins, Whales and Porpoises: 20022010 Conservation Action Plan for the World's Cetaceans. IUCN/SSC Cetacean Specialist Group. IUCN, Gland, Switzerland and Cambridge, UK.

Table 1. Confirmed blue whale sightings in the northwestern region of Chiloé Island during February and March, 2004

\begin{tabular}{|c|c|c|c|c|c|}
\hline $\begin{array}{l}\text { Sighting } \\
\text { Number }\end{array}$ & Date & Location & $\begin{array}{l}\text { Number of } \\
\text { Individuals }\end{array}$ & $\begin{array}{l}\text { Distance from coast } \\
(\mathbf{k m})\end{array}$ & Platform \\
\hline 1 & 24 February 2004 & $\begin{array}{l}41^{\circ} 50^{\prime} 03.6^{\prime \prime} \mathrm{S} \\
74^{\circ} 03^{\prime} 04.1^{\prime \prime} \mathrm{W}\end{array}$ & 6 & 1 & Land \\
\hline 2 & 25 February 2004 & $\begin{array}{l}41^{\circ} 52^{\prime} 53^{\prime \prime} \mathrm{S} \\
74^{\circ} 05^{\prime} 52^{\prime \prime} \mathrm{W}\end{array}$ & 3 & 5 & Boat \\
\hline 3 & 26 February 2004 & $\begin{array}{l}41^{\circ} 55^{\prime} 44.8^{\prime \prime} \mathrm{S} \\
74^{\circ} 01^{\prime} 45.1^{\prime \prime} \mathrm{W}\end{array}$ & 1 & $<1$ & Land \\
\hline 4 & 10 March 2004 & $\begin{array}{c}41^{\circ} 59^{\prime} 25.7^{\prime \prime} \mathrm{S} \\
74^{\circ} 03^{\prime} 00.5^{\prime \prime} \mathrm{W}\end{array}$ & 1 & 1 & Land \\
\hline 5 & 12 March 2004 & $\begin{array}{l}42^{\circ} 08^{\prime} 55.3^{\prime \prime} \mathrm{S} \\
74^{\circ} 12^{\prime} 53.3^{\prime \prime} \mathrm{W}\end{array}$ & 2 & 10 & Boat \\
\hline 6 & 15 March 2004 & $\begin{array}{l}41^{\circ} 49^{\prime} 32^{\prime \prime} \mathrm{S} \\
74^{\circ} 08^{\prime} 20^{\prime \prime} \mathrm{W}\end{array}$ & 3 & 7 & Plane \\
\hline
\end{tabular}

${ }^{3}$ IUCN (2004) 2004 IUCN Red List of Threatened Species. http:/ / www.iucnredlist.org. 